\title{
Biblical Exegesis in the Summa Halensis
}

\begin{abstract}
This essay analyzes the theory, structures, procedures and methods of biblical exegesis employed in the Summa Halensis. Like Peter Lombard's Sentences, whose form it adapts, the Summa is pervaded by biblical material, but it innovates by placing this material in an explicit theoretical relation to the human reflection surrounding it. After briefly examining the theory of interpretation contained in the Summa's first question, the essay surveys exegetical structures, procedures and methods. A final section compares a biblical question on John 3:23-4 from the Summa with contemporary John lectures by contributors Alexander of Hales and John of La Rochelle. Like those lectures, the Summa is fundamentally an exposition of 'theology's doctrine', which takes its rise from Scripture, but its professional literary context and mode of exposition differ.
\end{abstract}

My task in this paper is to consider the Summa Halensis as an exercise in interpreting the Scriptures. But what are the Scriptures, so far as the Summa is concerned? What is their source, their extent, their subject, their method, their purpose? How are they to be distinguished from other writings, and particularly from other forms of theological reflection? Finally, how are they to be used in a dogmatic exercise like the Summa? These are the questions that immediately occur to one attempting to problematize the Summa as an exegetical exercise. But they are not precisely the questions the Summists set themselves to answer in the introductory question, 'On the teaching of theology' (De doctrina theologiae). Their concern is for the body of teaching, or rather revelation, 'from God, about God and leading to God', which has Christ, the Incarnate Word at its core, the Scriptures as its mantle, conciliar, liturgical and patristic interpretation as its crust, and the shifting inquiries and disputations of the moderns as its surface and atmosphere. ${ }^{1}$

There was, in fact, no firm separation between the teaching of theology (doctrina theologiae) and the teaching of Sacred Scripture (doctrina sacrae scripturae) for the early Franciscans. ${ }^{2}$ For this reason, those terms and several others are used inter-

1 Alexander of Hales, Doctoris irrefragabilis Alexandri de Hales Ordinis minorum Summa theologica (SH) (Quaracchi: Collegium S. Bonaventurae, 1924-48), Vol I, TrInt, Q1, C2 (n. 3), Ad obiecta 1-4, p. 5: 'a Deo et de Deo et ductiva ad Deum' (English translations are the author's unless otherwise noted).

2 Heinrich Denifle, 'Quel livre servait de base à l'enseignement des maîtres en theologie dans l'Université de Paris?,' Revue Thomiste 2 (1894): 149-61; James R. Ginther, 'There is a text in this classroom: the Bible and theology in the medieval university,' in Essays in Medieval Philosophy and Theology in Memory of Walter H. Principe, CSB, ed. James R. Ginther and Carl N. Sill (Burlington, VT: Ashgate, 2005), 31-51. See also John Van Engen, 'Studying Scripture in the Early University,' in 
changeably in the question, 'On the teaching of theology'. However, the aims of a Summa and the disputations which make it up remain quite different than the aims of biblical commentary. The Summa attempts to take the teaching of Scripture and develop a systematic, comprehensive view of doctrine. The result incorporates a large amount of biblical exegesis. The Summa both passively appropriates the results of biblical interpretation from other sources and, to a lesser degree, actively parses the biblical text to assess its dogmatic import. This is very different from the exercise of the biblical lecture, where the master brings a variety of resources to bear for the purpose of interpreting the biblical book in hand line by line. At the end of this paper, I will demonstrate this difference by means of an exemplary comparison of the Summa to exegesis from the same period.

Although they looked to more contemporary Summae such as those of Praepositinus, William of Auxerre and William of Auvergne to shape their approach to theological topics, the basic literary structure adopted by the Summists came from Peter Lombard's Four Books of the Sentences. Happily, the historian of medieval exegesis Gilbert Dahan, in 2008, published an article entitled 'Le Livre des Sentences et l'exégèse biblique'. ${ }^{3}$ I have therefore adapted Professeur Dahan's model to this new, closely-related context. This article will analyze the Summa as an exegetical exercise, attending to its use of the theory, structures, procedures and methods of biblical exegesis. Like the Sentences, it is pervaded by biblical material, but it innovates by placing this material in an explicit theoretical relation to the non-biblical reflection surrounding it.

\section{Scripture as Source: Parameters and Distinctions}

The Bible is the fundamental written source of all Christian theological reflection, and therefore the most important source for the Summa. Although Jerome's Vulgate was the standard way of referring to Sacred Scripture for the Summists, they also make occasional reference to other versions: the Hebrew, Syriac and Septuagint Greek versions of the Old Testament, the Greek New Testament and the Old Latin versions of each. ${ }^{4}$

Neue Richtungen in der hoch- und spätmittelalterlichen Bibelexegese, ed. Robert E. Lerner (Munich: Oldenbourg Verlag, 1996), 17-38.

3 Gilbert Dahan, 'Le Livre des Sentences et l'exégèse biblique,' in Pietro Lombardo: atti del XLIII Convegno storico internazionale, Todi, 8-10 ottobre 2006 (Spoleto: Centro Italiano di studi sull'alto medioevo, 2007), 333-60.

4 See for example $S H$ I, TrInt, Q1, C1 (n. 1), Ad obiecta 3, p. 3 (Is 7:9 (Lxx)); SH I, P1, In2, Tr5, S2, Q4, Ti5, M4, C3, Ar2 (n. 265), arg. 1, p. 359 (Is 26:10 (Lxx)); SH II, In1, Tr1, S1, Q1, C3, Ar1 (n. 3), arg. 6, p. 6 (Ge 1:2 (Syr)); SH III, In2, Tr2, S1, Q1, Ti1, C1, Ar3 (n. 70), arg. 1, p. 86 (Job 40:14 (Lxx)); SH III, In2, Tr3, Q1, Ti2, M2, C2, Ar1 (n. 217), p. 228 (Ge 3:18 (VL)). 
The text and canon of Scripture assumed by the Summa appears to be that of the Paris Vulgate. ${ }^{5}$ These bibles, produced especially in Paris, but also in Oxford and Cambridge from about 1230, were among the first to employ the system of chapter numbers devised in the late $12^{\text {th }}$ century and associated with the name of Stephen Langton. ${ }^{6}$ Since there is no critical edition of the Paris Bible, its use in the Summa is inferred from two typological considerations: canon and chapter numbers. This canon contained the 66 books of the Old and New Testaments included in the English Bible, along with eight deuterocanonical books: the parabolic books of Tobit and Judith, the wisdom books of The Wisdom of Solomon and Ecclesiasticus (without the Prayer of Solomon at the end), the prophetic book of Baruch and three books of historiography: the third book of the Ezra-Nehemiah cycle, called 2 Ezra, and the first two books of the Maccabees. ${ }^{7}$

The overall biblical citation pattern of the Summa was also shaped by liturgical use. This explains the preeminence of Matthew among the other Gospels in the Summa, since Matthew predominated among the Gospel readings for Mass, and would have been most fully committed to memory. It also helps to explain the large proportion of references to Genesis and to the Psalms, although this is obviously balanced by their doctrinal importance. Books less frequently cited by the Summa I-III, such as Esther or Numbers, or altogether omitted, as are Jonah, Zephaniah, and 3 John, also occur infrequently in the liturgy.

The liturgy not only helped to determine what biblical texts are cited, but formed part of the authoritative tradition of secondary sources. ${ }^{8}$ Central parts of the liturgy, the Creeds (Apostolic and Athanasian) and the Canon of the Mass in particular, were

5 On the Paris text see Paulin Martin, 'La Vulgate latin au XIIIe siècle,' Muséon 7 (1888): 88-107, 169-96, 278-91, 381-93; Paulin Martin, 'Le Texte parisien de la Vulgate latine,' Muséon 8 (1889): 444-66; Paulin Martin, 'Le Texte parisien de la Vulgate latine,' Muséon 9 (1890): 55-70, 301-16; Robert Branner, Manuscript Painting in Paris During the Reign of Saint Louis (Berkeley: University of California Press, 1977), appendix I; Christopher De Hamel, The Book: A History of the Bible (New York: Phaidon, 2001), 114-39; Laura Light, 'Versions et révisions du texte biblique,' in Le moyen âge et la Bible, ed. Pierre Riché and Guy Lobrichon (Paris: Beauchesne, 1984): 55-93; Laura Light, 'French Bibles 1200-1300: A New Look at the Origins of the Paris Bible,' in The Early Medieval Bible: Its Production, Decoration and Use, ed. Richard Gameson (Cambridge: Cambridge University Press, 1994), 155-76.

6 Laura Light and Eyal Poleg, 'Introduction,' in Form and Function of the Late Medieval Bible, ed. Eyal Poleg and Laura Light (Boston: Brill, 2013), 1-7; typological description in Neil R. Ker, Medieval Manuscripts in British Libraries, vol. 1 (Oxford: Clarendon, 1969), VII-VIII.

7 There are also additions to 2 Chr 33 and Dn 13-14. See Ker, Medieval Manuscripts, 96-8; De Hamel, The Book, 120.

8 Victorin Doucet, 'Prolegomena in librum III necnon in libros I et II "Summae Fratris Alexandri”,' in Doctoris irrefragabilis Alexandri de Hales Ordinis minorum Summa theologica, vol. 4 (Quaracchi: Collegium S. Bonaventurae, 1948), xCIV. See Doctoris irrefragabilis Alexandri de Hales Ordinis minorum Summa theologica: Indices in tom. I-IV (Grottaferrata: Collegium S. Bonaventurae, 1979), 119: Breviary, 154: Missal, 164: Ritual, 165: Creeds. Note that Book 4, on the sacraments, is not included in the index. 
so important that they are themselves the subjects of exegesis within the Summa. ${ }^{9}$ The fact that the Summa Halensis, like other works of medieval systematic theology, was composed by people living a life arranged around formal communal prayer cannot be overemphasized.

But while prayer was fundamental to the Franciscan vocation, the primary professional task of the university theology master was to lecture on Sacred Scripture. Those lectures, particularly those by the Summa's known authors and redactors, are therefore fundamental for assessing its exegesis. We will therefore refer to the John Postils of John of La Rochelle and Alexander of Hales in order to draw some comparisons between the early Franciscan systematic and exegetical contexts. ${ }^{10}$

The set text for biblical lectures would not have been a one-volume Bible, but a volume of the book being lectured, accompanied by its traditional prolog(ues) and glossed throughout. The teaching of Scripture using glossed books accounts for the ubiquity of the Glossa ordinaria and Glossa Lombardi in the Summa Halensis. ${ }^{11}$ The Glosses codified an exegetical tradition based on a relatively small number of patristic commentaries for each book (for example, Augustine on Genesis, the Psalms and John, Jerome on Matthew, Gregory on Job), whose interpretations of the primary text were memorized, highly valued and only set aside with great reluctance. In assessing the Summa's interpretation of a biblical passage, therefore, a scholar's first reference must be to these Glosses, even if they are not explicitly cited.

All of this material as found in the Summa, whether biblical, liturgical or exegetical, has been transferred from its original context for the purposes of disputation. The literature of theological argument, as found in disputed questions, lectures on the Sentences and earlier Summae, forms the primary urtext of the Summa Halensis.

9 SH IV, P3, In2, Tr2, Q2, Ti1-3 (nn. 704-7), p. 1122-44; Alexander of Hales, Alexandri de Ales, Angli, Doct. Irrefragibilis, Ordinis Minorum, Summae Theologiae: Pars Quarta (hereafter cited as SH Bk IV), Q10, M5, Ar2 (Venice: Francesco Francesi, 1575), fols 152v-182v: Tractatus de officio missae; SH Bk IV, Q2, M2, Ar3, contra, fol. 13r.

10 John of La Rochelle, Postilla super Iohannem euangelistam (Ioh. hereafter) (Vatican City, Biblioteca Apostolica Vaticana, Vat. Lat. 7595, fols 1ra-96rb [Pref.-Jn 13:38]); see Appendix below; Alexander of Hales, Postilla in Iohannis euangelium, partial edition by Aaron Gies, 'Alexander of Hales on the Gospel of John: An Epitome of Sacra Doctrina' (PhD thesis, The Catholic University of America, 2017), 363-520 (In Ioh. hereafter).

11 See De Hamel, The Book, 136-37; Biblia latina cum glossa ordinaria, 4 vols (Strassburg: Adolf Rusch, 1480-1), Exemplars in Erfurt, Universität Forschungsbibliothek, Erfurt/Gotha Inc. 83 (1): urn:nbn:de:urmel-16903e29-15cd-40c4-a194-f9a2d553f634; Inc. 83 (2): urn:nbn:de:urmel-948998bb64d5-4eea-ae04-9d33957568589; Inc. 83 (3): urn:nbn:de:urmel-ebc3b6ea-d074-4b4c-85045c8e4e6d70795; Mon. Typ. s. 1. et a. $2^{\circ} 11$ (4): urn:nbn:de:urmel-c2ffaaa4-bae5-4e78-b5e689a31106253b6 (Gl. ord. in [biblical book, ref. \& in marg./interlin.] hereafter). See also the partial electronic edition Glossae scripturae sacrae-electronicae, ed. Martin Morard et al. (Paris: Centre national de la recherche scientifique/Institut de recherche et d'histoire de textes, 2016): http://glosse.irht.cnrs.fr/php/livres-liste.php; Peter Lombard, Collectanea in omnes D. Pauli apostoli Epistulas (also known as Magna glossatura) (PL 191:1297-1696; PL 192:9-520); Peter Lombard, Commentarium in Psalmos (PL 191:55-1296) (Gl. Lombardi in [biblical book \& ref.] hereafter). 
Therefore, as we now comment on sections of Question 1 which seem to bear directly on biblical exegesis, their limitations as a global assessment of the Summa's approach must be borne in mind.

\section{Hermeneutical Reflection in the Summa Halensis}

Until the emergence of university theology faculties at the end of the $12^{\text {th }}$ century, Latin biblical hermeneutics seem to have been mostly the province of standalone treatises, above all Augustine's On Christian Teaching, developed in the $12^{\text {th }}$ century by Hugh of St Victor's Didascalicon, On the Holy Scriptures and their Authors and The Diligent Examiner. ${ }^{12}$ In its first question, 'On the teaching of theology', the Summa Halensis follows the advance beyond the Sentences made by William of Auxerre and Roland of Cremona by explicitly calling into question the nature and status of the teaching of theology. In the process, the question makes many remarks that relate to Sacred Scripture specifically, and sketches its role in dogmatic argument. Most importantly for our purposes, it addresses Scripture's suitability to be a universal means of instruction and the possibility of deriving certain knowledge from it.

The purpose of Scripture, according to the 'Question on the teaching of theology', is 'instruction in those things that pertain to salvation'. ${ }^{13}$ This purpose is explicitly drawn from Rom. 15:4: 'For whatever was written previously was written for our instruction. ${ }^{14}$ This purpose appears to be somewhat at odds with the contents of the Bible, since its books convey meaning in a wide variety of ways, whereas, as the contra of this article states, paraphrased from Aristotle's Topics: ‘A uniform mode [of proceeding] is more suited to our instruction than a multiform [mode], because in a multiform [mode] understandings are confused.' ${ }^{15}$ Three kinds of 'multiformity' are being addressed here. The first is the multiformity of literary genres, since the Bible

12 Augustine, De doctrina christiana, ed. Joseph P. Martin (Turnhout: Brepols, 1962); Hugh of St Victor, Didascalicon de studio legendi, ed. Charles Henry Buttimer (Washington, DC: The Catholic University of America Press, 1939); English translation Hugh of Saint Victor, 'Didascalicon on the Study of Reading,' trans. Franklin T. Harkins, in Interpretation of Scripture: Theory, ed. Franklin T. Harkins and Frans van Liere, Victorine Texts in Translation 3 (Hyde Park, NY: New City, 2013), 81-201; Hugh of St Victor, De Scripturis et scriptoribus sacris (PL 175:9-28); Hugh of St Victor, Diligens scrutator, ed. Ralf M.W. Stammberger, 'Diligens scrutator sacri eloquii: An Introduction to Scriptural Exegesis by Hugh of Saint Victor Preserved at Admont Library (MS 672),' in Manuscripts and Monastic Culture: Reform and Renewal in Twelfth-Century Germany, ed. Alison I. Beach (Turnhout: Brepols, 2007), 241-83 ; See Gilbert Dahan, L'Exégèse chrétienne de la Bible en Occident medieval, XIIe-XIVe siècle (Paris: Cerf, 1999), $390-415$.

13 SH I, TrInt, Q1, C4, Ar3 (n. 6), Respondeo, p. 11: 'instructio in iis quae pertinent ad salutem.' 14 SH I, TrInt, Q1, C4, Ar3 (n. 6), Contra 1, p. 10: 'quaecumque scripta sunt ad nostram doctrinam scripta sunt.'

15 SH I, TrInt, Q1, C4, Ar3 (n. 6) Contra 1, p. 10: 'ad nostram doctrinam magis est modus uniformis quam multiformis, quia in multiformi condfunduntur intellectus.' 
contains not only logical arguments, but also historical and exemplary narratives, exhortations, prayers, commands, advice, prophecy, etc. The second are the traditional 'spiritual senses of Scripture', or, in the Summa's words, the 'fourfold sense': History, morality, allegory and anagogy, through which one and the same text can take on several nested meanings. ${ }^{16}$ The third is the mode whereby similar and dissimilar created symbols are dialectically applied to God in an attempt to more nearly express what is inexpressible.

The Summa defends Scripture's multiformity as especially suited for its purpose. While it is true that 'the intellect is more instructed by a few things', and that 'the uniform mode is plainer and easier than a multiform mode', ${ }^{17}$ this only applies when speaking of one particular learner. Because the primary efficient cause of Scripture (the Holy Spirit), and its material cause, the wisdom of God, are 'manifold' (Wis. 7:22; Eph. 3:10), it is fitting that the mode of Scripture is also manifold. ${ }^{18}$

The Summa then defends Scripture's multiformity as optimized for its universal purpose:

Since there are manifold states of human beings, under the Law, after the Law, in the time of prophets, in the time of grace; and also manifold states of human beings within these, since some are dull in what pertains to faith, others obstinate in what pertains to good morals; and also in different ways, since some live life in prosperity, some in adversity, some in good works, others in sins, it follows that the instruction of Sacred Scripture, which is ordered to the salvation of human beings, must have a multiform mode [of proceeding], so that the mode might correspond to the purpose. ${ }^{19}$

The Summa shows here a kind of awareness of author, circumstances and audience as informing biblical interpretation. These commitments will be observable in the exegetical methods and procedures it employs. At the same time, by acknowledging the

16 SH I, TrInt, Q1, C4, Ar3 (n. 6), arg. c, p. 10: 'quadruplex sensus'. On spiritual exegesis and the fourfold sense, see Henri de Lubac, L'Exégèse médievale: Les quatre sens de l'Écriture, 3 vols (Paris: Éditions Montague, 1959-61); English translation Henri de Lubac, Medieval Exegesis: The Four Senses of Scripture, trans. Mark Sebanc and E.M. Macierowski, 3 vols (Grand Rapids, MI: Eerdmans, 19982009); Manlio Simonetti, Profilo storico dell'esegesi patristica (Rome: Istituto patristico Augustinianum, 1981); Frances M. Young, Biblical Exegesis and the Formation of a Christian Culture (New York: Cambridge University Press, 1997); Dahan, L’Exégèse chrétienne, 37-74, 299-358.

17 SH I, TrInt, Q1, C4, Ar3 (n. 6), Ad obiecta 2-3, p. 11: 'intellectus magis instruitur per pauciora ( ... ) planior et facilior est uniformis quam multiformis.'

18 SH I, TrInt, Q1, C4, Ar3 (n. 6), Respondeo, p. 11.

19 SH I, TrInt, Q1, C4, Ar3 (n. 6), Respondeo, p. 11: 'cum ergo sint multiformes status hominum: in Lege, post Legem, tempore prophetiae, tempore gratiae; et etiam in is status multiformis hominum: quia alii hebetes in iis quae ad fidem, alii difficiles in iis quae ad bonos mores; et differentibus modis: alii in prosperis, alii in adversis vitam agunt, alii in bonis, alii in peccatis: relinquitur quod instructio sacrae Scripturae, quae est ordinata ad hominis salutem, debet habere modum multiformem, ut modus respondeat fini.' 
superiority of the uniform mode for instructing particular intellects, it defends the legitimacy of its own systematic mode of discourse.

The problem of deriving certain knowledge from Scripture is a problem with a specific type of multiformity: biblical narratives are made up of individual facts, of which there can be no universal knowledge, since it can never be self-evident that agent (A) did act (B) at time (C). The Summa solves this conundrum by asserting that those narratives, taken as a whole, express moral and theological universals, often by means of the fourfold sense. Reciprocally, those general realities elucidate and connect the diverse individual realities of Scripture and nature. Therefore, despite the uniform mode of proceeding proper to a Summa, biblical narratives and their spiritual interpretation retain a legitimate place among its sources. ${ }^{20}$ Let us now move on to consider the exegetical structures employed by the Summa in the course of its attempt to construct a systematic exposition of Christian doctrine.

\section{Exegetical Structures in the Summa Halensis}

When studying the Sentences, Gilbert Dahan proposed a twofold taxonomy of exegetical structures in systematic texts, corresponding to the dynamic of divine condescension in the pedagogy of human language and human ascension through the anagogy of theological interpretation. ${ }^{21}$ Corresponding to these descending and ascending movements, there are exegetical structures of 'passive exploitation', such as biblical testimonia and exempla, and structures of 'active exploitation', such as biblically-based questions and treatise-as-commentary. At the outset, it must be said that no exhaustive account of the exegetical phenomena in the Summa Halensis could be presented in so brief a space. The aim here is rather to present representative examples of each phenomenon for the student of the Summa, so that when similar instances are encountered elsewhere, they may be quickly identified and so more readily understood.

\section{Testimonia}

Biblical testimonia are the predominant form of exegetical structure in the Summa Halensis. They are structures of passive exploitation because as proofs, they bring along a tradition of interpretation which is often not even referred to, let alone argued, but assumed. They are of two basic types: chains of texts and distinctions.

20 SH I, TrInt, Q1, C1 (n. 1), Ad obiecta 3, p. 3.

21 Dahan, 'Le Livre des Sentences,' 344-5: 'l'exploitation passive (...) l'exploitation active'. 
Chains of texts are the oldest form of dogmatic argument, going back, in the Latin West, to Cyprian of Carthage. ${ }^{22}$ They consist of lists of biblical quotations introduced as authorities supporting a particular viewpoint. ${ }^{23}$ Although chains of texts might grow to great length in patristic polemics, the Summa rarely cites more than three in a row. A good example is furnished by Summa III's question, 'whether the passion of Christ befits divine justice', where three texts-Phil. 2:8, Heb. 5:8, and Rom. 8:32-drive home the third objection, from Anselm, that Christ's suffering was not merely permitted, but commanded by the Father. ${ }^{24}$ In the Summa, they should be categorized as a microstructure, rather than a structure, since they are always part of a larger question, contributing one or more sides of an argument to be resolved by a biblical distinction.

Since biblical authority could not be contradicted or simply ignored, the first and most important use of distinctions in scholastic theology was not to resolve philosophical propositions, but to resolve these apparently contradictory biblical testimonia. ${ }^{25}$ The distinction explains the difference, either by means of another authority, a rationale, or both. A good example of the basic mechanism is furnished by Chapter 1 of the question on divine immensity, "whether the divine essence is comprehensible or incomprehensible'. ${ }^{26}$ It appears so, but the first objection comes from Jer. 32:19: 'great in counsel, incomprehensible in thought'. This objection is supported by three more, from John Damascene, Augustine and Boethius. The sed contra of the argument cites four biblical texts that use comprehendere/comprehensibilis: Rom. 1:20: 'the invisible things of God (...) are clearly seen, being understood by the things that are made', Phil. 3:12: 'I follow, if I may by any means apprehend (comprehendam), wherein I am also apprehended (comprehensus sum)', Eph. 3:18: 'so that you may be able to comprehend with all the saints what is the length, width, height and depth', and 1 Cor. 2:10: 'the Spirit searches all things, even the deep things of God', adding, on the authority of the Glossa ordinaria, 'that is, makes us know'. The Summists have opposed Jeremiah's 'incomprehensibility' to optimistic statements about God's knowability from the New Testament, all of which seem to be taken in a limited sense. The solution proposes a basic twofold distinction: 'the cognition of the intellect of one who apprehends or clings to the truth can be called comprehension, or the cognition of the intellect that encloses (the subject considered)

22 Cyprian, Testimonium libri tres, in Sancti Cypriani Episcopi Opera, ed. Robert Weber and M. Bévenot, Corpus Christianorum Series Latina, 3 (Turnhout: Brepols, 1972), 1-179.

23 See Dahan, 'Le Livre des Sentences,' 345-48; citing Jean Daniélou, Études d'exégèse judéo-chrétienne (Les Testimonia) (Paris: Cerf, 1966); Jean Daniélou, Les origines du christianisme latin (Paris: Cerf, 1978), 217-39.

24 SH IV, P1, In1, Tr5, Q1, M4, C1, Ar1 (n. 151), arg. 3, p. 212. See Anselm of Canterbury, Cur Deus homo 1.8 (PL 158:370).

25 Dahan, L'Exégèse chrétienne, 134-8.

26 SH I, P1, In1, Tr2, Q2, C1 (n. 36), pp. 58-62: 'Utrum divine essentia sit comprehensibilis vel incomprehensibilis.' 
can be called comprehension. ${ }^{27}$ The divine essence is comprehensible by the human intellect according to the first definition, but not according to the second.

A more controversial example, opposing 'error' by testimonia, comes from Summa I's question, 'from whom is the procession of the Holy Spirit?'-the famous dispute over the filioque. ${ }^{28}$ The objections of the Greek Fathers are granted very scant biblical authority. Although there are 16 (!) objections, there are only three biblical citations..$^{29}$ The contra of the argument, itself 14 articles long, cites nine. ${ }^{30}$ The responses to the objections cite three further passages in support of the filioque. ${ }^{31} \mathrm{Ob}$ viously, the preferred position, bolstered by the best arguments available, is also given the strongest possible testimony from Scripture. Examples of such resolutions of conflicting testimonia by means of distinctions could be almost endlessly multiplied.

\section{Exempla}

Exempla are the second kind of passive exploitation of Scripture. An exemplum, according to Jacques Le Goff, is: 'a brief story given as truthful and destined to be inserted into a discourse (in general a sermon) in order to convince a hearer of a salutary lesson. ${ }^{32}$ To this, Dahan adds four criteria by which we may distinguish a biblical exemplum from other sorts of biblical exploitation: it must 1. play a secondary role, 2 . not be itself the subject of exegesis, 3. be employed as an illustration, and 4. have a narrative character. It is an aside, a biblical story employed as a Rabbi would midrashim, recounted for the sake of the moral lesson, perhaps adding a few extra details which are not strictly historical, but offered with no intention to mislead. ${ }^{33}$

In the Summa, biblical exempla are frequently reported as occurring in the authorities quoted, as in, 'Augustine gives the example of the rapture of Paul, I Corin-

27 SH I, P1, In1, Tr2, Q2, C1 (n. 36), Solutio, p. 59: 'potest appellari comprehensio cognitio intellectus apprehendentis sive adhaerentis veritati, vel potest appellari comprehensio cognitio intellectus includentis.'

28 SH I, P1, In2, Tr1, Q1, Ti2, C4 (n. 310), pp. 447-52.

29 Jn 15:26b (cited twice); Heb 1:3.

30 Mk 5:30; Lk 1:35; Jn 14:26; 15:26a; 16:13 (cited twice); 16:14; 20:22; Gal 4:6.

31 SH I, P1, In2, Tr1, Q1, Ti2, C4 (n. 310), p. 450, citing Jn 5:26; Gal 1:8; 1 Thes 3:10.

32 Claude Brémond, Jacque Le Goff, and Jean-Claude Schmitt, L'exemplum, Typologie des sources du Moyen Âge occidental, 40 (Turnhout: Brepols, 1982), 37-8; quoted in Gilbert Dahan, 'Quelques Reflexions Sur Les Exempla Bibliques,' in Le Tonnere des Exemples, ed. Marie Ann Polo de Beaulieu, Pascal Colomb, and Jacques Berlioz (Rennes: Presses Universitaires de Rennes, 2010), 19: 'un récit bref donné comme véridique et destiné à être inséré dans un discours (en général un sermon) pour convaincre un auditoire par un leçon salutaire.'

33 Dahan, 'Quelques reflexions,' 23, 25. 
thians 12. ${ }^{34}$ However, this is not, strictly speaking, a biblical exemplum. Quick references to biblical stories as proofs are common, but these do not have a narrative character, nor are they asides. ${ }^{35}$ To date, I have found only one example which I believe meets these criteria: In Summa III's discussion of sacrifice, there is a question asking 'whether sacrifice is to be offered to God alone?" ${ }^{36}$ One objection comes from Judg. 6:19: 'we read that Gideon "cooked a kid and unleavened bread and took it all and presented it to" the angel. Therefore Gideon presented a sacrifice to an angel. ${ }^{, 37}$ Two items in the sed contra are also narrative:

\begin{abstract}
Also, in Acts 14:12, 17, when "the priest of Zeus" wished "to sacrifice bulls" to Paul and Barnabas, they were prohibited by them with wailing, "lest they sacrifice to them" such things, from which they were obviously insisting that sacrifice is to be offered only to God.

Also, in Judges 13:16, an angel who was speaking with Manoah, said to him: "if you want to make a sacrifice, offer it to the Lord", in which he showed openly that sacrifice is to be offered to God, not to angels. ${ }^{38}$
\end{abstract}

The three examples are all brief narrative asides, not themselves the subject of exegesis, which support the main point by teaching a moral lesson. That Paul and Barnabus prohibited the men of Lystra 'with wailing' even furnishes a midrashic detail which is not in the text. However, the nature of the question, turning on the character of actions which are most conveniently described by means of a narrative, calls forth a mode of proceeding which is unusual in the Summa. Indeed, the brevity imposed by systematic argument is not conducive to this sort of passive exploitation, just as it is not conducive to long lists of testimonia.

\title{
Biblically-based questions
}

Moving on to consider structures of active exploitation, there are two that deserve particular consideration: biblically-based questions and treatise-as-commentary. Biblically-based questions turn on an issue of doctrinal coherence raised by a particular biblical passage. For example, the question 'on the sin of the first parents',

34 SH I, Tr Int, Q2, M1, C5 (n. 12), Contra b, pp. 21-2: '[Augustinus] point exemplum de Paulo in raptu, II Cor. 12.'

35 Dahan's only instance from the Sentences hardly seems to meet his own criteria. See Dahan, 'Le Livre des Sentences,' $348-9$.

36 SH IV, P2, In3, Tr 2, S3, Q5, C5 (n. 259), pp. 804-6: 'Utrum soli Deo sit sacrificium offerendum.' 37 SH IV, P2, In3, Tr 2, S3, Q5, C5 (n. 259), arg. 3, p. 805: 'legitur quod Gedeon “coxit hoedum et azymos panes, et tulit omnia et obtulit angelo”. Ergo Gedeon obtulit angelo sacrificium.'

38 SH IV, P2, In3, Tr 2, S3, Q5, C5 (n. 259), Contra e, f, p. 805: 'Item, Act. 14, 12, 17, cum “sacerdos Iovis” vellet "tauros" Paulo et Barnabae "sacrificare", cum eiulatione prohibiti sunt ab eis, "ne sibi” talia “immolarent”. Ex quo manifeste protestabantur soli Deo esse sacrificandum. Item, Iudic. 13, 16, angelus, qui loquebatur ad Manue, dixit ei: "Si vis sacrificium facere, offer illud Domino." In quo manifeste monstravit Deo, non angelis, esse sacrificium offerendum.' 
which covers 25 folio pages, depends mostly on exegesis of Gen. $3 .^{39}$ A biblicallybased question may also be structured around the reconciliation of a central doctrinal commitment, attested by many passages, with one particularly difficult passage, as with the question, 'Whether Christ paid tithes in Abraham', which attempts to reconcile the statement of Heb. 7:9 that 'Levi (...) paid tithes in Abraham' with that book's own doctrine of the greater perfection of Christ's priesthood, which would seem to be diminished by this kind of subordination. ${ }^{40}$

Certain biblical passages raise a number of closely-related questions, which are resolved one after another, resulting in what Dahan calls a 'treatise-as-commentary'. Prominent examples are Summa IIa's third inquiry, 'on corporal creation', which is essentially a commentary on the six days of creation, Gen. 1:1-2:25.41 Looking at the apparatus of this section, one observes that integral commentaries-Augustine's Literal Commentary on Genesis and On Genesis Against the Manichees, Bede's Hexaemeron, the Glossa ordinaria - are present in thick profusion. Another important treatise-as-commentary is Summa III's section, On the Decalogue, whose 185 folio pages are an extended treatment of Exod. 20:1-17.42 The predominant authorities here, the Glossa ordinaria and Lombardi, are also exegetical in character.

As mentioned above, the Mass and the Creed are also the subjects of line-by-line, even word-by-word exegesis. As might be expected, these texts being so closely related to Scripture, this exegesis does not confine itself to literal interpretation, but also extends into the spiritual senses. ${ }^{43}$ Having considered exegetical structures, let us go on to consider exegetical procedures.

\section{Exegetical Procedures in the Summa Halensis}

\section{Literal exegesis}

Exegetical procedures are methods by which exegesis is carried out, and occur in the Summa anywhere the biblical text is interpreted. ${ }^{44}$ Such procedures may be literal or spiritual. The most common literal procedures belong to the categories of textual analysis, literary analysis and contextual analysis. The tools of textual analysis include the determination of reference, ${ }^{45}$ the harmonization of texts, etymologies, lex-

39 SH III, In2, Tr3, Q1 (nn. 193-219), pp. 204-29: 'De peccato primorum parentum in se.'

40 SH IV, In1, Tr2, Q2, M4, C1 (n. 85), pp. 126-9: 'Utrum Christus decimatus sit in Abraham'; see esp. the Contra a, b, c, citing Heb 7:1-10; Ge 14:20; 14:18-19; Lk 15:8-9.

41 SH II, In3 (nn. 248-319), pp. 305-82: 'De creatura corporali.'

42 SH IV, P2, In3, Tr2, S1 (nn. 276-410), pp. 413-598: 'De praeceptis moralibus Decalogi.'

43 Spiritual interpretations of the liturgy were common in the Middle Ages; see Marcel Metzger, History of the Liturgy: The Major Stages (Collegeville, MN: Liturgical, 1997), 86-8.

44 See Dahan, 'Le Livre des Sentences,' 353-6; Dahan, L'Exégèse chrétienne, 239-358.

45 See Young, Biblical Exegesis, 137. 
ical interpretations and reference to versions other than the Vulgate, number symbolism, analysis of grammar, sentence structure and rhetoric. ${ }^{46}$ The tools of literary analysis are taken from the accessus ad auctores tradition, and include discussions of the text's author, genre, occasion, purpose, etc. ${ }^{47}$ The tools of contextual analysis include divisions of the text, a certain amount of historical or archeological research, and recourse to science, philosophy and theology (distinguished here from that which arises from allegorical readings of the text). ${ }^{48}$ The treatise-as-commentary on Genesis brings substantial outside expertise to bear on the biblical text, citing, among others, Aristotle's Physics, On the Heavens, On the Meteors and others for science, the Metaphysics for philosophy, Hugh of St Victor's On the Sacraments and Augustine's City of God for theology.

\section{Spiritual exegesis}

In the Summa Halensis, spiritual exegesis flows in principle out of historical or literal exegesis, but in practice often comes directly from authority. It is conducted according to the three traditional spiritual senses: tropological or moral, allegorical or Christological, and anagogical or prophetic. ${ }^{49}$ Such spiritual exegesis depends on the theology of revelation set out in the Summa's Introductory Treatise. As a spiritual reality, the fourfold sense is not to be reduced to a mechanical set of procedures. Rather, a number of discrete procedures are observable within the traditional categories, sometimes crisscrossing them.

Spiritual interpretations of Scripture may not always be left to stand, since they sometimes contradict one another. Usually the Summists simply omit the authority whose interpretation is to be rejected, but from time to time, there are determinations of authorities with explicit reference to spiritual exegesis. We see this procedure in the question, 'By which and how many figures the sacrament of the Eucharist was prefigured among the ancients?'50 The question turns on allegory of the type that is sometimes called typology, but has been better described by Frances Young as 'mimetic exegesis'. ${ }^{51}$ That is, it is concerned with interpreting persons, objects and events as icons of the Christ Event. This particular question goes back to Peter Lombard, who enumerated only four: the paschal lamb, manna, the offering of Melchize-

46 See Young, Biblical Exegesis, 208; Dahan, L’Exégèse chrétienne, 242-62.

47 See Young, Biblical Exegesis, 206; Dahan, L’Exégèse chrétienne, 262-71.

48 Dahan, L'Exégèse chrétienne, 271-97.

49 SH I, TrInt, Q1, C4, Ar1 (n. 4), pp. 7-9; SH I, TrInt, Q1, C4, Ar4 (n. 7), pp. 11-3.

50 SH Bk IV, Q10, M1, Ar2, fols 123r-124r.

51 Young, Biblical Exegesis, 209-15. 
dech and the blood which flowed from Christ's side at the Cross. ${ }^{52}$ Noting first that some have objected that this short list is insufficient, the Summists draw many more possible figures from direct biblical testimony, the Glossa Ordinaria, Ambrose's On the Mysteries, Augustine's On Christian Doctrine, The Canon of the Mass and Hugh's On the Sacraments. ${ }^{53}$ They retain eight: the Lombard's four, plus sacrifices, Gideon's offering of bread and meat, Jonathan's honeycomb, and the waters of Meribah. ${ }^{54}$

The question may seem superfluous at first glance-so much counting of patristic allegories, some of them quite fanciful to the modern eye. But the serious nature of the question becomes apparent in the response to the first objection:

[A]lthough he may not name all of the figures, it does not follow from this that [the list] is insufficient; for it was sufficient to name those which symbolized the sacrament most emphatically (...). [I]n the Sentences, the Master names those figures which expressly signified those things which coincide with this sacrament. ${ }^{55}$

The rationales for sufficiency are informative, but one need not choose from among them. Summists are really concerned to identify by means of mimetic exegesis, 'those things which coincide with this sacrament': what makes up the Eucharist itself. Choosing a set of symbols is a preliminary way to stake out a position on its significations. And indeed, the article that follows compares the eight figures with one another, whereupon the text moves on to consider the words of institution.

Summa III's question, 'whether personal tithes enter into the commandment to tithe', responds in the affirmative with two authorities: one from Gregory IX's Decretals supporting local determination of tithes for the support of the clergy, and the other an interpretation of Ps. 80:3 that would have been described as moral, but is better described by Young's taxonomy as oracular. After quoting the Psalm's command, 'take a psalm, and bring hither the timbrel', it gives Augustine's spiritual interpretation, as repeated by the Glossa ordinaria: 'this is said to laypeople, that is, take spiritual goods, and give temporal goods to the servants of God, so that they may be sustained. ${ }^{56}$ The Psalm is, in effect, understood as an oracle, intended by

52 Peter Lombard, Sententiae in IV libris distinctae 4, d. 8, c. 2, 2 vols, ed. Ignatius C. Brady, Spicilegium Bonaventurianum, 4-5 (Grottaferrata: Editiones Collegii S. Bonaventurae, 1971-81), 2:280 -1; citing Ge 14:18-20; Ex 12; 16; Jn 19:34.

53 SH Bk IV, Q10, M1, Ar2, fol. 123r; citing Ge 4; Lv 1-2; Nm 20; 1 Cor 10:3-4.

54 Lv 1, 2; Jgs 6:17-24; 1 Sm 14:24-45; Nm 20; 1 Cor 10:3-4.

55 SH Bk IV, Q10, M1, Ar2, fol. 123v: 'licet non ennumeret omnes figuras; non sequitur ex hoc, quod sit insufficiens; sufficiebat enim enumerare illas, quae expressius hoc sacramentum figurabant (...). Magister in Sententiis numerat illas figuras, quae expresse significabant ea, quae ad hoc sacramentum concurrunt.'

56 SH IV, P2, In3, Tr2, S2, Q3, Ti1, C4, Ar2 (n. 497), Respondeo, p. 735: 'dicitur laicis, hoc est sumite spiritualia a ministris Dei et date temporalia, unde sustententur’; citing Gl. ord. in Ps. 80:3 (Rusch, 
the Psalmist as a simple exhortation to praise, but by the Spirit as laying down an economic principle for the New Covenant to come. Exhortations to support the clergy, of course, could have been drawn from many other quarters in Scripture. Augustine cites many of them in the course of his exposition. But the authority of this oracular morality is, from the point of view of the Summists, adequate to anchor the response. Indeed, it is used again in the course of the question. ${ }^{57}$

An entirely different form of spiritual interpretation, also oracular, but this time allegorical/theological rather than moral, is evident in the question, 'how the articles are distinguished in the Apostle's Creed'. Part of a larger section on the Articles of Faith taken directly from John of La Rochelle's Summa on the Articles of Faith, the question divides the articles into 12 for the 12 Apostles, developing an extended allegorical exegesis on Josh. 4:2-3, where men chosen from each of the 12 Hebrew tribes construct an ebenezer out of stones picked from the middle of the Jordan river as they cross into Canaan. ${ }^{58}$ John, seconded by the other Summists, writes:

[The 12 Apostles], gathered into one by the inspiration of the Holy Spirit, each set out single articles. Peter, the first among the Apostles, set out the first article, namely, "I believe in God the Father almighty, maker of heaven and earth"; John set out the second, namely, "and in Jesus Christ his only begotten Son, our Lord". ${ }^{59}$

The text continues until each Apostle has had his say. This is allegory of a kind highly developed by the Victorines at Paris. It elaborates the plan of a structure: a temple, an ark, or, in this case, a pile of stones, and by assigning a particular meaning to each part, creates a balanced dogmatic theology. ${ }^{60}$ In the Didascalicon, Hugh of St Victor divides historical and spiritual exegesis by saying, 'History follows the order of time. But the order of learning belongs more to allegory because, as we said above, teaching should always take its beginning from manifest rather than obscure realities and from those things that are more well known. ${ }^{61}$ This division creates not

2:280v); see also Gl. Lombardi in Ps. 80:3 (PL 191:769); from Augustine, Enarrationes in Psalmos 80.4, ed. Eligius Dekkers and Jean Fraipont (Turnhout: Brepols, 2014), 1122-3.

57 SH IV, P2, In3, Tr2, S2, Q3, Ti1, C2 (n. 494), arg. 3, p. 730. See also SH IV, P2, In3, Tr2, S1, Q2, Ti4, C4, Ar4 (n. 350), Contra c, p. 519.

58 Jo 4:2-3; SH IV, P3, In2, Tr2, Q2, Ti1, C1 (n. 704), p. 1122; taken from John of La Rochelle, Summa de articulis fidei (Milan, Biblioteca Brera, AD. IX. 7), fols 78a-94b.

59 SH IV, P3, In2, Tr2, Q2, Ti1, C1 (n. 704), p. 1122: 'per inspirationionem Spiritus Sancti in unum congregati, singuli singulos apposuerunt articulos. Petrus, primus Apostolorum, primum apposuit articulum, scilicet "Credo in Deum Patrem omnipotentem, creatorem caeli et terrae”; Ioannes apposuit secundum, scilicet “Et in Iesum Christum Filium eius unicum, Dominum nostrum”,

60 See De Lubac, Medieval Exegesis, 3:312-5.

61 Hugh of St Victor, Didascalicon de studio legendi 6.6 (Buttimer, 123): 'Non idem ordo librorum in historica et allegorica lectione servandus est: historia ordinem temporis sequitur, ad allegoriam magis pertinet ordo cognitionis; quia, sicut supra dictum est, doctrina semper non ab obscuris, sed apertis, et ab is quae magis nota sunt exordium sumere debet'; cited in De Lubac, Medieval Exegesis, 3:312. English translation Hugh of Saint Victor, 'Didascalicon on the Study of Reading,' 173. 
two orders, but one twofold order: salvation-historical and systematic. This way of thinking can easily be recognized in the Summa's hermeneutics. Exegesis of Josh. 4:2, 3 invokes the 12 Apostles and the Creed by means of oracular allegory. Gathered together by the Holy Spirit in a scenario strongly reminiscent of Pentecost (Acts 2:1-4; Cf. John 17:22, 23), each Apostle utters an article of the Creed, forming a theological whole formed from literal and historical materials: the Articles of Faith.

\section{Comparison with Contemporary Franciscan Exegesis: John 3:23, 24}

To conclude our reflections, it will be useful to compare the exegetical practice of Alexander of Hales and John of La Rochelle with a biblically-based question from the Summa. Summa IV, Question 9, on the sacraments in general, includes two articles which ask 'whether the baptism of John had to cease', and 'when it ceased'. ${ }^{62}$ The answers turn on exegesis of John 3.

These theologians were chosen for comparison for very specific reasons. Alexander's name is closely associated with the Summa in many near-contemporary documents, and held the Franciscans' chair at Paris during the first years of its composition, ca. 1240-1245. His disputed questions underlie many of the Summa's. John of La Rochelle was de facto co-regent with Alexander at the Franciscan studium from 1238 to 1245 , when he also died. Many of his works are also incorporated into the Summa: we referred earlier to an included section of his Summa on the Articles of Faith. ${ }^{63}$ Both also have surviving John commentaries, which is not believed to be the case for Odo Rigaldus or William of Middleton. They are therefore the most relevant possible figures for comparison to the Summa's treatment of a passage of John's gospel.

The key authorities come from the Glossa ordinaria on the passage: John Scotus Eriugena's obscure and fragmentary Commentary on John (which the Summa and both postillators take to be Bede, possibly because of tagged Glosses, although the Glosses in the Rusch and Venice editions carry no attribution here), Augustine's Tractates on John, etymologies from Jerome's Letter Seventy-three and Hebrew Names. ${ }^{64}$ Verse 23, 'John was baptizing in Ennon near Salem', forms the contra of the first article, which necessitates distinctions to explain why, after Christ's baptism, John for a time continued to baptize. The contra also cites 'Bede' (actually John Scotus Eriuge-

62 SH Bk IV, Q6, M9, fols 61v-62r.

63 See above, p. 22.

64 John Scotus Eriugena, Commentarius in S. Evangelium secundum Ioannem (fragmenta iii) (PL 122:297-346), (Comm. in Ioh. hereafter); Jerome, Epistula 73, in Epistulae, ed. Isidore Hilberg, Corpus Scriptorum Ecclesiasticorum Latinorum, 55 (Vienna: F. Tempsky, 1912, repr. 1961), 13-23; Jerome, Liber interpretationis hebraicorum nominum, ed. Paul LaGarde (Turnholt: Brepols, 1959), 59-161, (Nom. hebr. hereafter). 
na), through the Gloss, who compares John's baptism to catechesis, which also continues after Christ's baptism. ${ }^{65}$ The second article uses a slightly longer selection of verses 23 and 24 to show that Christ's disciples baptized at the same time as John and his disciples, necessitating further distinctions to explain when and why John's baptism ceased.

In the Postilla super Iohannem euangelistam, John of La Rochelle breaks down the verse into four points, corresponding to four lemmata. ${ }^{66}$ First, he discusses John's ministry compared with that of Christ. He uses the authorities of 'Bede' and John Chrysostom to adduce reasons that baptism did not immediately cease when Christ began his ministry. ${ }^{67}$ Second, he discusses the place, Ennon near Salem, using 'Bede' and Jerome's comments, first on the actual location referred to, and then on the etymology of the words. ${ }^{68}$ John does not construct a moral interpretation from the etymologies. He takes Salim to be a village across the Jordan, as Eriugena and the Gloss say, but hesitates to identify it with Melchizedech's Salem, as Eriugena and the Gloss do, because of Jerome's warning about Hebrew's habitual omission of interior vowels. Ennon means 'waters' ${ }^{69}$ Third, he discusses what followed John's baptism, comparing it, again with 'Bede's' authority, to catechesis. Interestingly, he allows this authority to stand uncorrected, where the Summa limits the comparison in the response, because John's baptism is not necessary for those baptized, but continued catechesis is. ${ }^{70}$ Fourth, he discusses the time of the incident, still following

65 SH Bk IV, Q6, M9, Ar1, contra, fol. 61v; citing Gl. ord. in Ioh. [3:23] in marg. (Rusch, 4:1036ra); not found in Bede, but see John Scotus Eriugena, Comm. in Ioh. 3:24 (PL 122:323).

66 The Postilla super Iohannem euangelistam is a complete unedited set of gospel lectures by John of La Rochelle, probably dating to the 1230s or early 1240s, and extant in at least 14 manuscripts: Berlin, Staatsbiblotek Theologica Q. 40 [olim Rose 462], fols 1-122; Bologna, Archiginnasio A. 565; Danzig, Stadtbiblotek 1931, fols 1-159; Florence, Biblioteca Laurenziana Santa Croce X dext. 7; Krakow, Universitaria 1185 [AA X 27], fols 1-129 (1428); 1186 [AA X 26]; 1187 [AA X 28], fols 1-220 (1450); 1188 [AA $X$ 29]; Oxford, Merton College 80 (early 1400s); Padua, Biblioteca Antoniana 359; Vatican City, Biblioteca Apostolica Vaticana, Vat. Lat. 7595, fols 1-94; Vatican City, Biblioteca Apostolica Vaticana, Palatina lat. 124, fols 37-301; Vienna, Schotten 188/146, fols 1-115 (1359). Two more, in Ferrara and Toledo, are reported by Giovanni Giacinto Sbaraglia, Supplementum et castigatio ad scriptores Trium Ordinum Sancti Francisci a Waddingo aliisve descriptos (Rome: S. Michaelis ad Ripam, 1806), 12. A third, Dresden, Sächsischen Landesbibliothek, P. 36, fols 102-135, was almost completely destroyed by the Allied bombing in 1945. See Friederich Stegmüller and Klaus Reinhardt, Repertorium biblicum medii aevi (Madrid: Consejo Superior de Investigaciones Cientificas, 1949-80), 2:64, 8/2:267: http:// www.repbib.uni-trier.de/cgi-bin/rebihome.tcl, no 1111; Ignatius C. Brady, 'Sacred Scripture in the Early Franciscan School,' in La Sacra Scrittura e i francescani, ed. Roberto Zavalloni (Rome: Antonianum, 1973): 65-82; Beryl Smalley, The Gospels in the Schools, c. 1100-c.1280 (London: Hambledon, 1985), 74-6, 174-89.

67 Gl. ord. in Ioh. [3:23] in marg. (Rusch, 4:1036ra); from Eriugena, Comm. in Ioh. 3:23 (PL 122:322); John Chrysostom, Homilia in Iohannem 29.1 (Hom. in Ioh. herefter) (PG 59:167).

68 Gl. ord. in Ioh. [3:23] in marg. (Rusch, 4:1036ra); from Eriugena, Comm. in Ioh. 3:23 (PL 122:323); Jerome, Epistula 73.8 (Hilberg, 21).

$69 \mathrm{Gl}$. ord. in Ioh. [3:23] in marg. (Rusch, 4:1036ra); from Eriugena, Comm. in Ioh. 3:23 (PL 122:322). 70 See above, n. 65. 
'Bede', noting that John the Evangelist begins his treatment of Christ's ministry earlier than the other gospels, since the Baptist was not yet in prison. ${ }^{71}$

In the Postilla in Iohannis euangelium, ${ }^{72}$ Alexander begins his exegesis with a summary paragraph, saying that the verse discusses the baptism of John, noting first the time, then the cause. ${ }^{73}$ The reason for this passage, he says, is to show that the baptism of John ceased after Christ began his ministry, although, like circumcision, it ran concurrently for a time. ${ }^{74}$ He moves on to the place, moralizing on the etymologies, so that Ennon, 'waters', becomes 'eye of weeping or fount', signifying the penitential tears appropriate to John's baptism. 'Salim' becomes 'taking', and Melchizedech, 'the sending forth of death', thus signifying Christ's baptism, which takes away sin with its guilt and punishment. ${ }^{75}$

Alexander also takes his first reason for the cessation of John's baptism from 'Bede', ${ }^{76}$ but then moves directly to John's chronology relative to the Synoptics and explains John's imprisonment spiritually as the fulfillment of the Law with the coming of grace through Christ, following exactly the order of exposition in the Glossa ordinaria. He then digresses for Chrysostom's reason, introduced as a spiritual interpretation: John's baptism (i.e. the Law) continued for a time to better announce Christ's baptism (i.e. grace), and so that no one would believe it ceased out of zeal or anger. ${ }^{77}$

Both commentaries ask and answer questions, resolving apparent contradictions in the biblical text, mostly by expanding on the Glossa ordinaria, supplemented by Chrysostom's Homilies, which do not appear in the Summa's exegesis of this passage. ${ }^{78}$ Like the Summa, they both explain the text under consideration and offer theological interpretation. But, unlike the Summa, both early Franciscan masters

71 Gl. ord. in Ioh. [3:23] in marg. (Rusch, 4:1036ra); not found in Bede or Eriugena.

72 See Stegmüller and Reinhardt, Repertorium biblicum, nno 1151-4, 9960, 10521; Brady, 'Sacred Scripture,' 65-82; Smalley, Gospels, 230-54, 298-369; Abigail Ann Young, 'Accessus ad Alexandrum: the Prefatio to the Postilla in Iohannis Euangelium of Alexander of Hales (1186?-1245),' Mediaeval Studies 52 (1990): 1-23; Gies, 'Alexander of Hales on the Gospel of John,' 297-362.

73 Alexander of Hales, In Ioh. [3:23], §51 (Gies, 507).

74 Alexander of Hales, In Ioh. [3:23], §54-6 (Gies, 507-8).

75 Alexander of Hales, In Ioh. [3:23], §57-8 (Gies, 508); from Jerome, Nom. hebr. (LaGarde, 18, 66); Pseudo-Bede, Liber de interpretatione nominum hebraicorum (Basel: Johan Herwagen, 1563), col. 620; cf. Gl. ord. in Ioh. [3:23] (Rusch, 4:1036ra).

76 Alexander of Hales, In Ioh. [3:23], §59 (Gies, 509); Gl. ord. in Ioh. [3:23] in marg. (Rusch, 4:1036ra); from Eriugena, Comm. in Ioh. 3:23 (PL 122:322).

77 Alexander of Hales, In Ioh. [3:23], §60 (Gies, 509); John Chrysostom, Hom. in Ioh. 29.1 (PG 59:167). 78 John Chrysostom's apophatic teaching on the beatific vision, especially as stated in Hom. in Ioh. 15.1 (PG 59:98), was condemned in 1241. SH II, In4, Tr3, Q4, M2, C1, Ar1 (n. 517), Respondeo, p. 764, explicitly denounces this view. Still, the indices to the $S H$ attest reference to him throughout, although this reference is very unevenly distributed. Doucet, 'Prologomena,' LxxxIV, LXxxIx, counted the references: SH I (3), SH II (5), SH III (173), SH IV (56). Book 4 has not been indexed, but Chrysostom is also cited there, for example $S H$ Bk IV, Q4, M7, Ar1, resp., fol. 40v; citing John Chrysostom, In Hebraeos 2.1 (PG 63:20). 
focus on the respective purposes of the baptisms of John and of Jesus. Neither exegete explicitly solves the question of timing, but the Summa clinches it with Augustine's comment on John 1:29, 'The Lord was baptized in the baptism of John, and when John was put into prison, thereupon John's baptism ceased. ${ }^{79}$ This is perhaps because the aims of the two texts are different. The exegetes are giving an exposition of the Gospel, which is offering an account of the consummation of John's ministry in that of Jesus, whereas the Summa is attempting to render an orderly and consistent account of the sacraments.

\section{Conclusion}

While adapting the overall structure of the Lombard's Sentences, the Summa Halensis advances beyond them by offering an account of its own hermeneutic, the way in which the teaching of theology arises in Scripture and proceeds so as to instruct people of all ages and conditions in the knowledge necessary for salvation. While the Summa's purpose differs from that of biblical commentary in attempting to offer a systematic account of Christian doctrine, it is still pervaded by exegetical material. Indeed, we have been able to detect every exegetical device enumerated by Dahan in connection with the Sentences. Even the most philosophically-rigorous theology in the early Franciscan school is aimed at the practical purpose of salvation. Nonetheless, the distinction between the systematic and exegetical modes of theological instruction implies a distinction in proximal purpose. This becomes visible when we attend to the actual differences in the questions raised and conclusions reached by early Franciscan biblical commentaries and the Summa. While the Summa aims to render an orderly account of dogma so that it does not always treat every relevant passage of Scripture, but always (or nearly always) answers the question raised, the commentaries attempt to follow the purposes of the Holy Spirit speaking through the human author(s) as made explicit in their division of the text, so that not every question which may be of interest to the student of dogmatic theology is asked and answered. Perhaps the most important conclusion for this provisional look at exegesis in the Summa Halensis is that there is much to do before any definitive statement can be made. Not only Summa IV, but the exegesis of the Lombard and his school, as well as that of the early Paris Franciscans and Dominicans, must be edited if we are to trace the relationship between lectio and disputatio with greater precision. We have noticed, particularly with respect to testimonia and exempla, that Dahan's taxonomy does not perfectly fit the Summa. It may need to be revised as we learn more about exegesis in the period of the Summa's composition. Still, what can be seen at present

79 SH Bk IV, Q6, M9, Ar2, resp., fol. 62r: 'Baptizatus est Dominus baptismo Ioannis, et cessauit baptismus Ioannis inde missus est in carcerem Ioannes'; citing Augustine, In Iohannis evangelium tractatus 4.14, ed. D.R. Willems (Turnhout: Brepols, 1954), 38. 
is sufficient to show that Scripture, the primary locus of authority in the Christian tradition, was also a locus of innovation in early Franciscan thought. 


\section{Appendix: John of La Rochelle, Postilla super Iohannem euangelistam [3:23, 24]}

Vatican City, Biblioteca Apostolica Vaticana, Vat. Lat. 7595, fol. 26vb, ln. 4-46

Erat autem Iohannes. Introducitur baptisma/ Iohannis et primo quidam nobis occurrit persona baptizantis cum dicitur/ Erat autem Iohannes baptizans, ubi aduertendum quod secundum Augustinum |ा baptizabat Iohannes quia oportebat ut Christus ab eo bap-/ -tizaretur. Non solum autem Christi ab eo baptizatus est, sed multi alii, ne baptismus Iohannis melior baptismate Do-/ -mini uideretur. Si enim solus Christus fuisset baptizatus a Iohanne,/ non deessent qui ${ }^{80}$ dicerent usque adeo magnus erat baptis- /-mus quem habuit Iohannes ut solus Christus illo fuerit dignus/ baptizari. Tा Notandum est quod Christo baptizante adhuc Iohannes/ baptizat, cuius prima ratio, secundum Bedam, est quia nondum precursor ces-/ -sare donec ueritas perfecte manifestetur. Secunda ratio, secundum Chrysostomum,/ est quia si Iohannes statim cessasset, posset existimari a mul-/ -tis quod hoc fecisset zelo uel ira. Et ideo non statim cessauit, sed/ baptizans non sibi gloriam acquirebat, sed Christo auditores multipli-/ -cabat, ${ }^{81}$ et multo efficacius hec faciebat quam discipuli Christi./ Secundo nobis occurit locus in quo Iohannes baptizabat, et ideo dicitur/ quod erat baptizans in Enon iuxta Salim, ubi aduertendum/ est primo quod Salim, secundum Bedam, opidum est iuxta Iordanem/ situm ubi olim Melchisedech regnauit. Secundum Iero-/ -nimum autem non refert uniuersaliter Salem aut Salim nominetur/ cum uocalibus $^{82}$ in medio litteris, raro utantur Hebrei et/ pro uoluntate lectorum et regionum uariente eadem uocabula/ diuersis sonis atque accentibus proferantur. Secundum notandum quod/ Enos hebraice dicitur aqua, et ideo Euangelista hanc inter-/ -pretationem aperiens subdit quia multe aque erant illic./ Tertio nobis occurrit fructus quid sequitur ex baptismo Iohannis,/ et ideo dicitur in litteram quod ueniebant et baptizabantur. Tा Notandum/ est secundum Bedam quod ita se habebat tunc baptismus Iohannis ad bap-/ -tismam Christi, sicut nunc cathezismus in quo baptizandi/ instruuntur in fide et properantur ad baptismam se habunt ad/ baptismam uerum. Sicut enim Iohannes predicabat primam et/ baptismam Christi prenuntiabat, et in cognitionem ueritatis que/ in mundo apparuit attrahebat, sic ministri ecclesie/ primo erudiunt uenientes ad fidem. Prima peccata eorum redar-/ -guunt, demum in Christi baptismo peccatorum remissio-/ -nem promotunt. Et sic Johannes attrahunt homines ad cog-/ -nitionem ueritatis et amorem. Quarto nobis occurrit tempus ${ }^{83}$ / quo hec facta sunt quando dicitur, nondum enim missus fuerat Iohannes/ in carcerem, ubi secundum Bedam aduertere possumus quod Iohannes/ Euangelista cepit

80 qui] que $m s$.

81 multiplicabat] multiplicebat $m s$.

82 uocalibus] uocabulis corr. in marg. a. $m$.

83 tempus] ipse ms. sed corr. a. m. 
narrare facta Christi ante Iohannem incarce-/ -ratum, que alii euangeliste pretulerunt, incipientes ab/ hiis que post Iohannem missum in carcerem facta sunt. 
